\title{
Odbezpieczyć teologię albo dać jej zginąć (uwagi o esejach Jacoba Taubesa)
}

Lektura książek Alaina Badiou, Slavoja Žižka i Giorgia Agambena o Pawle apostole prawdopodobnie aż nadto dobrze utrwaliła tezę mówiąca, iż kryzysy religijne dzielą wiele z doświadczeniami rewolucji. Dla porządku trzeba przypomnieć, że tym, który bezdyskusyjnie przyczynił się do obecnego wskrzeszenia tego tematu był Jacob Taubes (1923-1987), wygłaszając w obliczu zblizającej się śmierci wykłady o teologii politycznej Pawła ${ }^{1}$. Właśnie otrzymujemy drugą część niewielkiego dorobku Taubesa, mianowicie większość rozproszonych rozpraw pisanych przez niego na przestrzeni całego życia ${ }^{2}$. Ich różnorodnej problematyce nie sposób sprostać w jednym tekście, dlatego ograniczę się do stwierdzenia,

1 J. Taubes, Teologia polityczna świętego Pawta: wyktady wygtoszone w Ośrodku Badań Ewangelickiej Wspólnoty Studyjnej w Heidelbergu 23-27 lutego 1987 roku, tłum. M. Kurkowska, wstęp Z. Krasnodębski, Warszawa 2010. Nie dość przypominania, że oryginalny tytuł brzmi Die Politische Theologie des Paulus - jego polskie tłumaczenie fałszuje podstawową intencję Taubesa, jaką było przedstawienie Pawła w roli odnowiciela religii żydowskiej, a nie chrześcijańskiego świętego. Krytyczne omówienie wstępów do prac Taubesa zamieszczonych przez polskich wydawców znajduje się w recenzji Apokalipsy i polityki autorstwa Mikołaja Ratajczaka, zob. M. Ratajczak, Teologiczne pasaże: o ksiażce „Apokalipsa i polityka: eseje mesjańskie” Jacoba Taubesa, „Kultura Liberalna”, http://kulturaliberalna.pl/2013/07/02/ratajczak-teologicznepasaze-o-ksiazce-apokalipsa-i-polityka-eseje-mesjanskie-jacoba-taubesa/.

2 Tegoż, Apokalipsa i polityka: eseje mesjańskie, tłum. zbior., Warszawa 2013. 
że składają się na ten tom między innymi: eseje będące polemiką z koryfeuszami dwudziestowiecznego odrodzenia myśli żydowskiej (Martinem Buberem, Franzem Rosenzweigiem, Gershomem Scholemem), dokumentujące spór z Carlem Schmittem, a także teksty poświęcone najważniejszym teologom doby nihilizmu (Franzowi Overbeckowi, Adolfowi von Harnackowi, Karlowi Barthowi), u nas niezauważonym. Niewielkie objętościowo rozprawy i szkice Taubesa można uważać za wnikliwy zapis doświadczenia kogoś, kto wżył się całym sobą we współczesny mu czas, chcąc przemyśleć, co złożyło się na aktualny stan rzeczy.

W liście do Armina Mohlera, datowanym 14 lutego 1952 roku, Taubes przystaje na pogląd Carla Schmitta, że jedyną rzeczywistą paralelę historyczną dla współczesności stanowi niespokojny początek „naszej ery” ${ }^{\prime 2}$ Kwestią centralną jest tu status Prawa. Działalność Jezusa i Pawła, gnostyków oraz innych sekt tamtego czasu podkopała fundament rzymskiej państwowości. Przypuszczony został atak na „kosmiczną pobożność”, która poprzez mediację filozofii gwarantowała legitymizację porządku politycznego. Co zostało w żydowsko-gnostycko-chrześcijańskim tyglu obalone, później restytuowało samo chrześcijaństwo w dobie Konstantyna Wielkiego. Sojusz z Imperium przypieczętował „pierwszą sekularyzację" $^{4}$ tej religii, wyrosłej na sprzeciwie wobec skandalu Ukrzyżowanego podług Prawa. Nowożytność to epoka korozji wszelkich struktur hierarchicznych i ostateczny upadek autorytetu, co w sposób oczywisty ponownie stawia Prawo pod znakiem zapytania.

I z całą pewnością - pisze Taubes we wspomnianym liście - pytanie o prawo musi dzisiaj zostać zadane „teologicznie” - to znaczy zapytać trzeba, jak wygląda prawo, jeśli zakładamy, że naszym losem jest ateizm? Czy bez prawa boskiego Zachód musi utonąć we krwi i własnym szaleństwie? A może sami zdołamy wyprowadzić prawo i bezprawie z „ziemsko-śmiertelnej sytuacji człowieka”.

Wszystkie analizy Taubesa bazują na przekonaniu o polemicznej naturze pojęć $c^{6}$. Nie inaczej ma się rzecz z pojęciem „teologii”, które „zostało ukute w czasach kryzysu" ${ }^{7}$, mianowicie stworzył je Platon w momencie gdy gruntował na nowo polityczność grecką, jednocześnie poddając

3 Tamże, s. 444-445.

4 H. Blumenberg, Legitimacy of the Modern Age, tłum. i wstęp R.M. Wallace, Cambridge-London 1999, s. 45-46.

5 J. Taubes, Apokalipsa i polityka..., s. 445.

6 Zob. tegoż, Teologia..., s. 61, 99 i n.

7 Tegoż, Apokalipsa i polityka..., s. 299. 
krytyce stary panteon bogów oraz tradycyjne ideały. Polityczny wymiar koncepcji teologicznych był przez Taubesa jeszcze silniej akcentowany w wypadku religii monoteistycznych. Uważał on, powołując się na Zygmunta Freuda, że cień Boskiego Rodzica długo jeszcze kłaść się będzie na poczynaniach jego dzieci - obojętnie, czy uznamy je za prawomocne, czy też buntownicze - dlatego niebezpiecznym przeoczeniem byłoby ignorowanie teologicznej genealogii naszych słowników ekonomicznych, prawnych i politycznych. „Dopiero gdy unieważniona zostanie uniwersalna zasada władzy, jedność teologii i teorii politycznej zostanie usunięta. Krytyka teologicznego elementu w teorii politycznej ostatecznie opiera się na krytyce samej zasady władzy"8.

W akcentowaniu silnej więzi między teologią a polityką Taubes podąża w ślad za swym wielkim adwersarzem, Carlem Schmittem, ale z intencją przeciwną do niego. Obaj stwierdzają kryzys demokracji wynikający z „rewolucyjnego przełomu w myśli XIX wieku”, ale wyciągają z tego rozbieżne wnioski. Taubes bowiem uważał, że wszelkie próby

przywrócenia porządku hierarchicznego w epoce demokratycznej skazane są na porażkę, pozostając romantyczną nostalgią lub przyjmując postać totalitarnego koszmaru, skoro kosmologiczne, epistemologiczne i teologiczne założenia porządku hierarchicznego uległy zniszczeniu ${ }^{10}$.

By pojąć dzieje tego rozpadu, nie wystarczy sięgnąć pamięcią do stulecia, które przyszło po rewolucji francuskiej. Rewolucja ta bowiem zaledwie podsumowała pewien wielowiekowy proces korozyjny.

Podobnie jak Alexandre Kojève w 1968 roku rekomendował protestującym studentom, by uczyli się greki, tak Taubes współczesnym dziedzicom rewolucji zdaje się mówić, by - nawet zanim zabiorą się za lekturę

8 Tamże, s. 309.

9 K. Löwith, Od Hegla do Nietzschego: rewolucyjny przetom w myśli XIX wieku, tłum. S. Gromadzki, Warszawa 2001. Taubes przyznał się do znaczącego wpływu, jaki ta książka odegrała w jego wczesnym życiu intelektualnym, przeczytał ją w rok po publikacji (1941): „Wszystko, czego się wcześniej dowiedziałem na temat duchowej i intelektualnej historii dziewiętnastego wieku, wydało mi się płytkie i pozbawione znaczenia” (J. Taubes, Apokalipsa i polityka..., s. 428). Wpływ tej rozprawy Löwitha można także odnotować, śledząc w tekstach Taubesa niechlubną praktykę zapożyczania cudzych koncepcji (zob. tamże, s. 457, 459).

10 Tamże, s. 302 (wyróżnienie moje - RZ). Jednocześnie Taubes zaznacza, że nie można powiedzieć, iż w dawniejszych czasach, kiedy obowiązywała klasyczna kosmologia, hierarchia była czysto ideologiczną nadbudową (tamże, s. 303). Jednak głoszenie jej dziś jako wiążącej zasady organizującej społeczeństwa jest wyłącznie albo świadectwem głupoty, albo cynizmu. 
Karola Marksa - przeczytali Le système du monde ${ }^{11}$ Pierre'a Duhema, a jeśli już nie mają czasu na te dziesięć tomów, to koniecznie powinni sięgnąć przynajmniej po Die Genesis der kopernikanischen Welt ${ }^{12}$ Hansa Blumenberga. Ktoś mógłby spytać: tylko po co? Otóż jeśli chcemy odzyskać ów „zaginiony skarb rewolucji” (Arendt), powinniśmy wejść w intelektualny sojusz z tymi, którzy jako pierwsi poruszyli stary świat w posadach,zanim rozpadł się on pod naporem procesów ekonomicznych i związanych z nimi rewolucji społecznych. W kontrowersyjnej książce O rewolucji (1963) Hanna Arendt zwróciła uwagę na fakt, że revolutio to słowo pochodzące $\mathrm{z}$ astronomii, oznaczające cykliczny ruch ciał niebieskich, powracający do punktu wyjścia. Pierwszy raz zostało ono odniesione do polityki podczas glorious revolution, gdzie użyto go ze względu na restaurację władzy po wygnaniu Stuartów. Dopiero osiemnastowieczne rewolucje - amerykańska i francuska - przyniosły rewizję samego pojęcia, odkrywając zdolność do zaczynania na nowo, ustanawiania początków ${ }^{13}$.

Arendt postawiła tezę, że o rewolucji można mówić wyłącznie od czasów nowożytnych, a uzasadniała to wzrastającym samorozumieniem ruchów radykalnych, które zaczęły przedkładać zerwanie nad kontynuację. Na skutek głębokich przekształceń mentalności okresu reformacji porzucono mniemanie, że praca łączy się z biedą oraz że podział na biednych i bogatych jest czymś naturalnym, przyrodzonym. W zmianie form życia zbiorowego z pomocą przyszło drugie znaczenie terminu revolutio - nieodzowność - co znalazło wyraz w osiemnasto- i dziewiętnastowiecznym necessaryzmie ${ }^{14}$. Wszystko to byłoby jednak niemożliwe bez zakwestionowania rudymentarnych założeń kosmologicznych, które od czasów antycznych aż do późnego średniowiecza służyły za gwarant hierarchicznego ładu - religia zapewniała przecież boską sankcję władzy.

Taubesa łączy z Arendt przekonanie o możliwości wyłonienia się polityki demokratycznej dopiero wraz z demontażem dawnego obrazu wszechświata, jednak dokonuje w tej narracji pewnych korekt ${ }^{15}$. Po pierwsze, przypomina, że synteza platońsko-arystotelesowska była tamą przed materialistycznym atomizmem jako filozofią potencjalnie wywro-

11 P. Duhem, Le système du monde: histoire des doctrines cosmologiques de Platon à Copernic, t. 1-10, Paris 1913-1959.

12 H. Blumenberg, Die Genesis der kopernikanischen Welt, Frankfurt am Main 1981.

13 H. Arendt, $O$ rewolucji, tłum. M. Godyń, posłowie P. Nowak, Warszawa 2003, s. 47-48.

14 Tamże, s. 23, 54-56.

15 Nie stwierdzam tutaj żadnego bezpośredniego związku refleksji Arendt i Taubesa nad zagadnieniem rewolucji, a tylko dokonuję zestawienia. 
tową. Po drugie - i to dla Taubesa stanowi kwestię zasadniczą - pomiędzy klasyczną myślą grecką a średniowieczem, na obrzeżach uświęconego właśnie państwa Augustów, dochodzi do dziejowej detonacji, która pozostała początkowo niezauważona, a później opacznie usensowniona ${ }^{16}$. Bliski Wschód przełomu er to miejsce politycznie niestabilne, gdzie atmosfera dojrzewa do rebelii Żydów przeciw Rzymowi. Dają o sobie znać rewolucyjne, gnostyckie idee, obecne - zdaniem Taubesa - od zarania w teologicznym arsenale judaizmu, ale skutecznie tłumione przez przywódców religijnych ${ }^{17}$. Na pograniczu religii związanych z ideą transcendencji (pozaświatowego Boga) dokonano deprecjacji samej podstawy antycznej pobożności i etyki, postulując antykosmizm, czyli odmawiając uniwersum (immanencji) prawa do bycia sensotwórczym źródłem ${ }^{18}$. Ten przewrót był dziełem ludzi, którzy oscylowali na granicy ortodoksji i herezji ${ }^{19}$.

Wreszcie trzecia poprawka Taubesa wobec opowieści Arendt polega na przesunięciu początków nowoczesności na „jesień średniowiecza”, a nawet i wcześniej, bo w czasy joachimitów, katarów i franciszkańskich spirytuałów $^{20}$. W późnośredniowiecznej ikonografii (Dürera, Bruegla,

16 „Krytyczna analiza podstawowych pojęć chrześcijańskich wykazuje, że już w następnym pokoleniu po Pawle oryginalne znaczenia podstawowych kategorii jego teologii popadły w zapomnienie" (J. Taubes, Apokalipsa i polityka..., s. 115).

17 O genetycznych związkach judaizmu i gnozy był przekonany nauczyciel Taubesa, Gerschom Scholem. Tezę taką wysuwa także m.in. żydowski badacz Guy Stroumsa, zob. G.G. Stroumsa, Another Seed: Studies in Gnostic Mythology, Leiden 1984.

18 Rangę tych dramatycznych przekształceń uchwycił i opisał jako pierwszy Hans Jonas, kolejny ważny dla Taubesa autor, w dziele Gnosis und spätantiker Geist (tom 1 ukazał się w 1934 r., tom 2 - w 1954 r. Polskie tłumaczenie oparte jest na amerykańskim, skróconym wydaniu z 1958 r., zob. H. Jonas, Religia gnozy, tłum. M. Klimowicz, Kraków 1994). Tekst Taubesa Cnota i wiara: studium zachodniej terminologii etycznej (J. Taubes, Apokalipsa i polityka..., s. 101-107) to właściwie powtórzenie ustaleń Jonasa.

19 Taubes już w doktoracie (Abendländische Eschatologie, Bern 1947) zaprezentował wizję dziejów Zachodu, które nawiedza i ożywia eschatologiczny pożar, umożliwiający odradzanie się prawdziwie ludzkiego żywiołu, czyli Historii.

20 Jest to teza idąca po myśli Karla Löwitha (zob. rozdział 8 jego Historii powszechnej...: K. Löwith, Historia powszechna i dzieje zbawienia: teologiczne przestanki filozofii dziejów, tłum. J. Marzęcki, Kęty 2002), a polemiczna wobec Hansa Blumenberga, który przełom nowożytny interpretował jako odpowiedź na „prowokację" teologii, a odpowiedzią tą miałby być zupełnie świecki świat budowany z pomocą przyrodoznawstwa i techniki. Natomiast Taubes był zdania, że „schemat: Starożytność - Wieki Średnie - Epoka Nowożytna, to nic innego jak zsekularyzowana wersja Joachimowego »trynitarnego« schematu historii" (J. Taubes, Apokalipsa i polityka..., s. 223). 
Boscha) Taubes dopatruje się kryptogramów z zakazanymi treściami, jakie w formie pisanej zostały zniszczone przez oficjalny Kościół ${ }^{21}$. Reformacja jest dla niego, podobnie jak rewolucja francuska, symptomem przeciążenia, na które złożyły się wysiłki wcześniejszych buntowników. Niezachwiana pozostaje w Taubesie wiara w „utajony żywot” pewnych idei, które nieraz przez długi czas istnieją w ukryciu i czekają na sposobną okazję reaktualizacji.

Interesują go duchowe eskapady do takich krytycznych momentów dziejowych, kiedy wszystko mogło się wydarzyć. Taka była sytuacja Pawła, który nie wiedział, że swoją działalnością doprowadzi do powstania nowej religii. Z równie enigmatyczną przyszłością musieli radzić sobie marrani i ich potomkowie - stara wiara okazała się niemożliwa, nowej zaś nie było. Marrański typ świadomości uważał Taubes za znak nadchodzącego oświecenia, które doprowadziło do demitologizacji i niwelacji znaczenia różnic międzywyznaniowych ${ }^{22}$. Ta niwelacja działała jak miecz obosieczny, bowiem stojący za nią sceptycyzm relegował co prawda problem wojen religijnych do lamusa historii, jednocześnie jednak dezaktywując samą teologię: pod naporem historyzmu powstało $\mathrm{w}$ dziewiętnastym wieku typowo niemieckie zjawisko „religii kulturowej”, usłużnej wobec państwa i społeczeństwa mieszczańskiego. Kolejna formacja pokoleniowa odrzuciła tę hipokryzję - przeciw zeświecczonej religii, nie zostawiając na niej suchej nitki, występowali zarówno „grabarze” chrześcijaństwa, jak Overbeck, jak i jego radykalni apologeci, jak Barth $^{23}$.

Gdyby chodziło tylko o los jakiejś dyscypliny akademickiej - w tym wypadku teologii chrześcijańskiej - można by ten problem uznać za lokalny. Tymczasem Taubes łączył wyłonienie się teologii dialektycznej (zwanej nie bez powodu teologią kryzysu) z katastrofalnym tąpnięciem, jakim dla Zachodu była pierwsza wojna światowa ${ }^{24}$. Co więcej, uważał, że właśnie „»teologia kryzysu“ ukazywała ducha tych czasów wierniej niż jakakolwiek filozofia, socjologia czy antropologia, wciąż tkwiące w optymizmie myśli dziewiętnastowiecznej" ${ }^{25}$, natomiast o metodzie dialektycznej samego Bartha napisał, że „stanowi być może najdonio-

21 Tamże, s. 305.

22 Tamże, s. 8 i n.

23 Zob. więcej: „Kronos” 2012, nr 4 (numer tematyczny „Teologia niemiecka”).

24 Cezura ta jest konstytutywna również dla myśli Agambena, który przyznaje się do inspiracji Taubesowskich.

25 J. Taubes, Apokalipsa i polityka..., s. 251. 
ślejszy wkład w powszechną świadomość naszej epoki”26. Zatem teologia pełniła dla Taubesa funkcję historycznego barometru, a co najważniejsze, mogła „wspierać stanowisko krytyczne wobec wiecznego dogmatyzmu zdrowego rozsądku" 27 .

Tarapaty, z jakich próbowała się wywikłać teologia dialektyczna, były udziałem całego życia umysłowego. Chodzi o wspomniany sceptycyzm historyzmu ${ }^{28}$. Taubes interpretuje to zjawisko w kategoriach religijnych, dostrzegając pośród konsekwencji historyzmu możliwość restytucji pogaństwa w znaczeniu anihilacji judeochrześcijańskiego sposobu przeżywania czasu. Jeśli - jak chce Löwith, a Taubes mu w tym wtóruje - schedą po religiach monoteistycznych są futurystycznie nastawione filozofie dziejów, to wraz z wyczerpaniem się wiary w transcendencję (dodajmy, na skalę masową, ponieważ dopiero to wpływa na konieczność reorientacji życia społecznego) kończy się także model uczasowienia zasadzający się na nadziei radykalnej odnowy ${ }^{29}$. Te lęki o „przyszłość pewnego złudzenia” nie są wcale nieuzasadnionym histeryzowaniem. Prorokowane i postulowane przez Nietzschego odrzucenie pozostałości po religii w pewnej mierze już się dokonało - tak na poziomie społeczeństwa, jak i filozoficznego samoopisu. Otóż kapitalistyczny rytm pracy, produkcji i konsumpcji, oparty na modelu czasu neutralnego, nieznającego wyjątków-świąt, wzmacnia dwa wymiary temporalności obce doświadczeniu judeochrześcijańskiemu: cykliczność oraz natychmiastowość bez żadnego oczekiwania.

Adwersarzami filozoficznymi Taubesa afirmującymi finis Christianismi byli Hans Blumenberg i Odo Marquard. Pierwszy zaatakował tezę o sekularyzacji, broniąc świeckiej nowoczesności przed podejrzeniami o ukrytą zależność od teologii. Na przykład idea postępu nie jest dla Blumenberga zeświecczoną eschatologią i przejawem pychy rozumu

26 Tamże, s. 233.

27 Tamże, s. 235.

28 Rekonstrukcję historyczną tego stylu myślenia, który zdominował naukę począwszy od dziewiętnastego wieku, przedstawia Herbert Schnädelbach w kontekście upadku systemu Hegla i późniejszych prób odbudowy filozofii, zob. H. Schnädelbach, Filozofia w Niemczech 1831-1933, tłum. K. Krzemieniowa, Warszawa 1992.

29 W książce poświęconej „teologicznym przesłankom filozofii dziejów” Löwith pisze, że idea postępu jest pochodną „żydowsko-chrześcijańskiego futuryzmu”, którego negację stanowi cykliczność, ponieważ „w ramach cyklicznego porządku wszechświata, gdzie każdy postęp jest zarazem regresem, nie ma miejsca na nieodwracalny postęp”. I dalej: „Idea postępu obowiązuje i upada wraz z antycypacją przyszłości i supozycją, że przyszłość przynosi coś nowego", zob. K. Löwith, Historia powszechna..., s. 107 (wyróżnienie odautorskie).

Kapitalistyczny rytm pracy, produkcji i konsumpcji, oparty na modelu czasu neutralnego, nieznającego wyjątkówświąt, wzmacnia dwa wymiary temporalności obce doświadczeniu judeochrześcijańskiemu: cykliczność oraz natychmiastowość bez żadnego oczekiwania 
instrumentalnego (czytaj: i grzechu pierworodnego), lecz odpowiedzią na kryzys naukowy po upadku antyczno-średniowiecznej kosmologii. Wygórowane ambicje wczesnonowożytnych głosicieli postępu noszą co prawda ślad wcześniejszych niespełnionych oczekiwań, ale ta retoryczna przesada wynika raczej z presji czasu, jest strategią obronną przed zagrożeniem radykalnego zwątpienia. Marquard z kolei, po udanym techniczno-naukowym opanowaniu świata w nowożytności, którego prawomocności bronił Blumenberg, postanowił stępić te wygórowane ambicje jako nieuzasadnione po ukonstytuowaniu się uhistorycznionej antropologii filozoficznej. W wydanej w 1973 roku pracy pod znaczącym tytułem Schwierigkeiten mit der Geschichtsphilosophie [Kłopoty z filozofią dziejów $]^{30}$ postanowił uporać się z utopiami politycznymi, co miało być przede wszystkim definitywną rozprawą z marksizmem.

Taubes doskonale rozumiał pozycje obu filozofów, ale uważał je za krótkowzroczne. Blumenberg i Marquard postanowili bowiem uciąć gałąź, na której sami siedzą, próbując wygasić nadzieje, jakie napędzały impet rozwojowy Neuzeit, jak gdyby chcieli powiedzieć: „To było może dobre kiedyś, ale dziś jesteśmy już zbyt dorośli, zbyt sceptyczni, żeby to dalej ciągnąć”. Broniąc dostatniej, bezpiecznej i sytej „doczesności” przed zagrażającym jej „mrzonkom” wszelkiej maści fantastów, apokaliptyków i rewolucjonistów, nie dostrzegali - tak można odczytywać pełną niezgody postawę Taubesa - decydującego cywilizacyjnego konfliktu, jaki rozpętał się po pierwszej wojnie światowej i który może zdecydować o przyszłości pewnego uniwersalistycznego projektu, jaki nazywa się „Zachodem”. Linie podziału w tym konflikcie przebiegają tak, jakby odrodziła się konstelacja późnego, dekadenckiego antyku: z jednej strony nastawieni krytycznie wobec „tego świata” religijni rebelianci (szantażowani przez zachowawcze religie instytucjonalne, które odczuwają ich działalność jako wyrzut sumienia i oskarżenie o haniebny kompromis), z drugiej przeważający żywioł pogański wraz ze swymi „terapeutycznymi” szkołami (epikureizmem, sceptycyzmem, cynizmem) uwznioślającymi pojednanie z immanencją, $\mathrm{z}$ braku wiary w skuteczność działania politycznego preferującymi wycofanie się w sferę prywatną, w kontemplację, rozrywkę itd.

W takich warunkach, kształtujących klimat opinii od początku dwudziestego wieku, doszło do „recydywy gnozy” ${ }^{31}$. Taubes uznał, że nie przypadkiem po ponad siedemnastu wiekach Marcjon, chrześcijański gnostyk, zaczął być obiektem zainteresowania teologów i filozofów. Pisali

30 O. Marquard, Schwierigkeiten mit der Geschichtsphilosophie, Frankfurt am Main 1973.

31 J. Taubes, Apokalipsa i polityka..., s. 177. 
o nim m.in. von Harnack i Barth, Buber i Bloch, zaś piętno „gnostyckiej struktury"32 doświadczenia odcisnęło się, zdaniem Taubesa, także na myśli Waltera Benjamina, Simone Weil i Ludwiga Wittgensteina. Gnoza rozumiana jest tu jako radykalna krytyka świata w jego zastanej postaci. Oczywiście nie chodzi o odrodzenie wiary w pozaświatowego Boga, który byłby jedyną poręką zbawienia. Jeśli mowa o „cytowalności” gnozy ${ }^{33}$, to chodzi raczej o powrót pewnego sposobu doświadczenia siebie i świata (felt sensibility, jak mówi Benjamin Lazier), z którego - po „przetłumaczeniu” go na język nowoczesny - wiele się po drodze wytraciło. W dyskusji z Hansem Blumenbergiem Taubes przyznaje, że utrata pozaświatowego kontekstu w nowożytności drastycznie zmienia sytuację, jednak nie oznacza to niemożliwości pojawienia się światopoglądu gnostyckiego nawet w naszych czasach ${ }^{34}$. Nie jest tak, jak chciałby Blumenberg: nowożytność nie była udanym przezwyciężeniem gnozy, o czym świadczy klimat duchowy w Niemczech lat dwudziestych ubiegłego wieku.

$\mathrm{Z}$ drugiej strony Taubes chce bronić też innej flanki: po odsunięciu argumentów Blumenberga-Marquarda - obrońców liberalno-mieszczańskiego centrum, pragmatyzmu i nieskrępowanego panowania za pomocą techniki - trzeba było uratować „utracony skarb rewolucji” przed anatemą rzuconą przez Erica Voegelina, który chciał zdekonspirować nowoczesność przez uznanie jej za wylęgarnię form gnozy politycznej, które dokonują niebezpiecznej „immanentyzacji transcendencji” 35 , to znaczy chcą ustanowić raj na ziemi. Taubes, o ile rozumiem pokrętność jego zamysłu, proponuje ryzykowny krok dogłębnego przemyślenia tych prawicowo-konserwatywnych zarzutów pod adresem progresizmu, przyjęcia ich i przechwycenia. Jak lubił powtarzać: les extrêmes se touchent ${ }^{36}$. Dlatego Juana Donoso Cortésa i Pierre'a Proudhona ujmował zawsze łącznie, widząc w ich wyborach wyciągnięcie skrajnie odmiennych wniosków

32 Tamże, s. 130.

33 Tamże.

34 Taubes w tej kwestii sytuuje się pomiędzy Blumenbergiem a Jonasem. Ten drugi w zakończeniu rozdziału o marcjonizmie napisał: „Całkiem zaś niezależnie od doktrynalnych kontrowersji przesłanie Marcjona głoszące nowego i obcego Boga będzie zawsze znajdywało oddźwięk w ludzkiej duszy", zob. H. Jonas, Religia..., s. 162 .

35 E. Voegelin, Nowa nauka polityki, tłum. i wstęp P. Śpiewak, Warszawa 1992. Taubes oponuje przeciw Voegelinowi przede wszystkim w ten sposób, że nie wyraża zgody na dzielenie chrześcijaństwa na bierną politycznie duchowość i gnozę polityczną wyrosłą z eschatologii.

36 Dlatego nie było dla niego nie do pojęcia, że Carl Schmitt, późniejszy „jurysta Trzeciej Rzeszy”, mógł w pewnym momencie zostać zwolennikiem Lenina, i to wcale nie przez lekkomyślność, zob. J. Taubes, Teologia..., s. 203. 
z tej samej sytuacji historycznej, nieprzewidywalności świata porewolucyjnego wytrąconego z kolein - jeden chciał go za wszelką cenę stabilizować, drugi jeszcze bardziej wykoleić, by nie utknął w połowie drogi do rzeczywistych przemian.

Co ma do tego gnoza? Przemyślana do końca, skutkuje dwoma przeciwstawnymi zaleceniami: z jednej strony, aby przyjąć postawę jak najbardziej bierną, gdyż zmiana położenia nic nie da, z drugiej, aby ten świat zniszczyć, skoro nie można go reformować. Pomiędzy tymi psychohistorycznymi skutkami pewnych dość dobrze znanych teologemów można upatrywać drogi wyjścia, jaką byłaby gnoza dialektyczna, która neguje świat w całości po to, żeby go uratować, a nie zniszczyćc ${ }^{37}$. A co ma do tego rewolucja? Otóż ta wysoce antynomiczna, krytyczna wobec rzeczywistości postawa, wcielona w Historię, musi skutkować postulatami stałej teoretycznej i praktycznej podejrzliwości wobec wszelkiej władzy, przymusu i opresji. Taubes przypomina o teologicznych źródłach tak radykalnego buntu. W przypadku gnozy był to protest przeciw antycznej pobożności, dlatego Żydów, chrześcijan i gnostyków często oskarżano o ateizm. Trzeba pamiętać o tej stygmatyzacji, by obelga nie została uwewnętrzniona. W tym kontekście rozumiem stwierdzenie Taubesa, że „satanizm” niektórych dziewiętnastowiecznych rewolucjonistów nie był „metaforą literacką”, lecz „wyrazistą zasadą intelektualną” ${ }^{38}$. Demoniczność stanowiła na ówczesnym etapie walki jedyną skuteczną formę protestu wobec tych, którzy nie wyobrażali sobie rodziny, państwa ani religii bez Ojca. Wyrastała jednak tylko w powiązaniu z całkowicie na serio traktowaną świętością, którą należało dopiero sprofanować, aby pozbyć się satanicznej aury wytwarzanej właśnie w zakazanym kontakcie z sacrum.

Rozchodzi się tu o subtelne związki między teologią i polityką. Nie trzeba wcale przyjmować substancjalistycznego stanowiska tezy o sekularyzacji, żeby te związki zauważać. Nie wolno nie pamiętać - jeśli wierzy się w ocalającą moc żywej, problematyzującej pamięci - że przed pojawieniem się w traktatach Machiavellego, Hobbesa czy Spinozy

37 Taubes pod koniec życia potrafil powiedzieć: „I have no spiritual investment in the world as it is" (tamże, s. 204), ale jeśli mamy uratować jego myślenie dla świata, a samego Taubesa przed zarzutem o polityczny nihilizm, to trzeba szukać innych odpowiedzi niż te, jakich on sam udzielał na postawione przez siebie pytania. Warto też przy okazji zastrzec, że pomimo fascynacji gnozą Taubes był wobec niej krytyczny. Ponad rodowicie gnostycki ideał autarkii wynosił judeochrześcijańską miłość bliźniego, która świadczyła o przyznaniu się do niesamowystarczalności (tamże, s. 129).

38 Tegoż, Apokalipsa i polityka..., s. 428. 
zalążki idei demokratycznych kiełkowały w anarchistycznej atmosferze późnośredniowiecznych stowarzyszeń i grup heretyckich, wędrownych kaznodziejów i artystów ${ }^{39}$. Współczesna demokracja natomiast doprowadziła do obalenia wcześniejszego porządku symbolicznego z sakralną lokalizacją Ojca, ma zatem przynajmniej „coš” wspólnego z ojcobójstwem, królobójstwem i - ostatecznie - bogobójstwem ${ }^{40}$, co oczywiście nie oznacza, że mamy do czynienia z reżimem diabolicznym. Taubes chce w swoich uwagach zmieścić się pomiędzy anatemą i apologią. Dlatego rozumie, że walka emancypacyjna niekiedy zbliża się do bluźnierstwa, ale zostaje otwartym pytanie, na ile wynika to z diaboliczności buntowników, a na ile z nieustępliwości „rodzicielskiej” władzy, która tę diaboliczność prowokuje.

Rewolucjoniści powinni pamiętać, że są spadkobiercami pewnego zwątpienia. To mogłoby ich chronić przed rozczarowaniem. Mając bowiem na uwadze niebezpieczeństwo prowokacji do nierównej walki, można łatwiej obronić własne postulaty przed zarzutem o ,immanentyzację transcendencji”. W tym miejscu postawa Taubesa przybiera formę wewnętrznej opozycji. Jego koncepcja „negatywnej teologii politycznej” staje na drodze prostej aplikacji, sprzeciwia się zbyt pośpiesznemu przekładowi teorii na praktykę, który nie dbałby o konsekwencje: „Każda bowiem próba sprowadzania zbawienia na poziom historii bez przeobrażenia samej idei mesjańskiej wiedzie wprost do przepaści”¹ . Przeobrażeniem tym jest uwewnętrznienie. Jego logika odsyła do hermeneutyki kryzysów religijnych, które w oczach Taubesa podzielają ten sam los, co rewolucje polityczne, będąc w istocie rewolucjami. Interesują go przykłady skrajne: wczesny chrystianizm oraz sabataizm. W obu wypadkach grupa wyznawców musiała się zmierzyć z opresją czasu ${ }^{42}$ oraz rozczarowaniem z powodu niespełnionej obietnicy. Gdyby nie uwewnętrznienie, ruch mógłby okazać się efemerydą. Co więcej, chrześcijaństwo, zdaniem Taubesa, zawdzięcza przetrwanie właśnie temu, że zdołało zreinterpretować śmierć Jezusa. Dzieje idei mesjańskiej to opowieść o jej utajonym życiu mimo historycznej klęski: apokaliptyka była odpowiedzią na „niespełnione proroctwa”, gnoza na „niespełnioną apokaliptykę”³, z kolei gnoza dialektyczna - można by dopowiedzieć - jest postacią, w jakiej utrwaliło się rozczarowanie względem Boga-suwerena i jego opatrzno-

39 Tamże, s. 453-454.

40 Tamże, s. 450-451.

41 Tamże, s. 10.

42 Tamże, s. 487.

43 Tamże, s. 185. 
ściowej mocy. Ale też nie ma czego żałować, skoro - jak uważał Ernst Bloch, orędownik rewolucyjnej gnozy - idea Stworzyciela tyleż otwierała perspektywę czasu wychylonego w przyszłość, co zamykała usta jakiejkolwiek krytyce, zaś „ekonomia zbawienia” ostatecznie działała jak prostacka pedagogika, która gasi ogień Objawienia ${ }^{44}$.

Na koniec uwaga o metodzie, jako że eksperymenty Taubesa z myśleniem teologicznym mogą nastręczać trudności. Nie każdego przekona religijna interpretacja świata i polityki (np. Marks jako piety$\left.\mathrm{sta}^{45}\right)$. Jeśli jednak zaryzykować, to może się okazać, że teologia całkiem dobrze tłumaczy niezwykle istotny dla myślenia o polityce fenomen przechodzenia do działania, mówi o powodach niemożności tego przejścia czy o decydującej roli czasu. Wydaje się, że nie warto lękać się teologii, bardziej natomiast należy lękać się o nią samą. Ostatnie słowa oddaję Jacobowi Taubesowi, dedykując je nieprzekonanym:

W moim myśleniu nie kieruję się kryteriami teologicznymi. Zajmuję się jedynie teologicznymi tekstami, myślę jednak z perspektywy historii mentalności. Szukam potencjału politycznego w teologicznych metaforach, podobnie jak Schmitt szuka potencjału teologicznego pojęć prawnych ${ }^{46}$.

44 Tamże, s. 181.

45 Tamże, s. 478.

46 Tamże, s. 151. 
RAFAŁ ZAWISZA (1988) - absolwent Kolegium MISH UW. Przygotowuje pracę na temat znaczenia filozoficznej refleksji nad natalnością. Zajmuje się myślą Hanny Arendt i Hansa Blumenberga, filozofią postsekularną oraz historią gnozy. Członek redakcji czasopisma „Praktyka Teoretyczna”. Publikował m.in. w „Kronosie” i „Praktyce Teoretycznej”.

\section{Dane adresowe:}

Rafał Zawisza

Wydział „Artes Liberales”

Uniwersytet Warszawski

ul. Nowy Świat 69

00-046 Warszawa

e-mail: rafal.w.zawisza@gmail.com

\section{Cytowanie:}

R. Zawisza, Odbezpieczyć teologię albo dać jej zginać (uwagi o esejach Jacoba Taubesa), „Praktyka Teoretyczna” nr 2(8)/2013, http://www. praktykateoretyczna.pl/PT_nr8_2013_Teologie_emancypacyjne/15. Zawisza.pdf (dostęp dzień miesiąc rok)

\section{Author: Rafał Zawisza}

Title: To release the safety catch of theology or to let it perish (notes about Jacob Taubes' essays). 